\title{
Complementary and alternative treatment methods in chronic rheumatic diseases in the Central Anatolia
}

\author{
Ahmet Karadağ ${ }^{1}$, Emrullah Hayta ${ }^{1}$ Ece Kaptanoğlu², Akın Konak ${ }^{3}$
}

\begin{abstract}
Background: The aim of the study is to identify the kind of traditional practices used for the rheumatic diseases in the central Anatolia.

Materials and Methods: A total of 440 volunteer patients with chronic rheumatic diseases including osteoarthritis (OA), fibromyalgia, rheumatoid arthritis (RA), spondyloarthropathy (SpA), familial Mediterranean fever (FMF), Behçet's disease (BD), systemic lupus erythematosus (SLE), and mixed connective tissue disease (MCTD) were enrolled in the study. All patients were administered a 36-item questionnaire.

Results: Of the patients, $49.3 \%$ were using CAM. Herbal medicine was the most commonly (58.1\%) preferred methods. The CAM was used by 86 (48\%) of 179 patients with OA and by 51 (60\%) of 85 patients with RA. The difference in the CAM use across the disease groups was not statistically significant $(\chi 2=7.343 ; p=0.290)$. When the patients using or not using CAM were assessed according to their education status, it was found that CAM was used by 59 (66.3\%) of 89 patients with university degree and indicating a statistically significantly higher number of patients from higher education status among the CAM users $(x 2=17.651 ; p=0.001)$.
\end{abstract}

Conclusions: Our study results suggest that among patients with rheumatic disease, patients with RA more commonly resort to the methods of CAM.

Keywords: rheumatic disease, central anatolia, alternative treatment, complementary medicine

\section{INTRODUCTION}

Complementary and alternative medicine (CAM) is a concept that is used for applications other than conventional treatments (1). CAM is widely used throughout the world (2). However, the CAM methods vary according to geographical and cultural characteristics (3-5). Rheumatic diseases are inflammatory diseases or non-inflammatory chronic diseases. Conventional treatment methods (e.g., drugs, physical therapy, surgical treatment, rehabilitation programs) are used successfully in rheumatic diseases. However, the treatment methods used are not curative and sometimes they can be insufficient in the treatment of these diseases. Therefore, patients with rheumatic disease try to use CAM methods (6-9).

In previous clinical trials, the rates of CAM use for rheumatic diseases are different as well as preferred CAM methods (10-14).

We should note that in the relevant literature, there are limited number of clinical studies on the use of CAM in Turkish patients with rheumatic disease, which needs to be explored. Additionally, in previous clinical trials, only one rheumatic disease was investigated and both cultural and religious values of Turkish patients were not considered.

In this study, we aimed to determine the frequency of CAM use and the most commonly used CAM methods in Turkish patients with rheumatic disease in the central Anatolia. We further aimed to determine patients with which rheumatic disease were more tend to use CAM methods.

\footnotetext{
Cumhuriyet University, Faculty of Medicine, Department of Physical Therapy and Rehabilitation, Sivas, Turkey.

2 Cumhuriyet University, Faculty of Medicine, Department of Rheumatology, Sivas, Turkey.

3 Cumhuriyet University, Faculty of science and literature, Department of Anthropology, Sivas, Turkey.
}

Correspondence: Ahmet Karadağ

Cumhuriyet University, Faculty of Medicine, Department of Physical Therapy and Rehabilitation, Sivas, Turkey.

E-mail:dr_ahmetkaradag@hotmail.com

Received: 16 Jan 2018, Accepted: 3 Mar 2018

(C) 2018 by the authors; licensee Modestum Ltd., UK. This article is an open access article distributed under the terms and conditions of the Creative Commons Attribution License (http://creativecommons.org/licenses/by/4.0/). 


\section{PATIENTS AND METHODS}

We recruited 440 consecutive patients (296 females, 144 males; mean age: 47.40 14.09 years; range: 17-84 years) who were diagnosed with a rheumatic disease including osteoarthritis (OA), fibromyalgia (FMS), rheumatoid arthritis (RA), spondyloarthropathy (SpA), familial Mediterranean fever (FMF), Behçet's disease (BD), systemic lupus erythematosus (SLE), and mixed connective tissue disease (MCTD) (13) in the outpatient and inpatient clinics of Physical Therapy and Rehabilitation Department of Cumhuriyet University, Medical School were enrolled in this study between September 2011 and June 2012 in the Central Anatolia. All participants were included on the basis of voluntary enrollment and none of them had a communication problem which precluded the administration of the questionnaire. Patients with communication disorder that interfered with the patient's ability to complete the questionnaire, patients with any psychiatric disorder, and patients who did not give consent to complete the questionnaire were excluded.

This study was approved by our University Ethics Committee and was conducted in accordance with the principles of the Declaration of Helsinki. A written informed consent was obtained from each study participant.

\section{THE QUESTIONAIRES}

Face-to-face interviews were performed in the majority of the patients and a 36 -item survey was completed after providing CAM definition. The questionnaire was developed by a rheumatologist, statistician, and an anthropologist. Before administration of the questionnaire, comprehensibility and applicability of the questions were confirmed by administering the questionnaire to a pilot group of 50 participants. (validation rate $\% 92 ; \alpha=0.874$ ). The questionnaire was therefore deemed suitable for use in the present study.

\section{CAM}

A treatment that is not prescribed or included within the biomedical frame in the treatment of rheumatic diseases (16). The survey addressed socio-demographic characteristics (name, surname, date of birth, gender, educational status, occupation, monthly income, current residence, marital status, coverage of health insurance, educational status of parents, availability of healthcare services in the place of residence), medical characteristics (diagnosis, patient's level of information on their disease, treatment modality, date of diagnosis comorbid conditions, current or previous therapies), source of information about CAM, beliefs and expectations regarding CAM, reason for CAM use, whether they informed their clinicians regarding non-medical therapies, frequency of CAM use, CAM methods used (lead, tomb visit, good-luck charms, praying, coiling up with fish, leech, knotting, coiling up with wool and stones electromagnetic devices, supportive devices, tapes, and drug advertised in TV), references for CAM and cost, which period they tried CAM and whether they used CAM simultaneously with medical treatments, benefits or adverse effects and reasons for not trying CAM if the patient did not attempt to use CAM.

In the evaluation of obtained data, SPSS version 22.0 software was used for statistical analysis. Chi-square or Fisher's Exact test, if necessary, was used in the comparison of categorical data. Normal distribution of data was analyzed using the Kolmogorov-Smirnov test. Student's t-test, variance analysis, and One-way AANOVA Tukey test were used when parametric test assumptions were met. Descriptive data were expressed as the number of individuals, percentage, and mean \pm standard deviation in the tables. A $p$ value of $<0.05$ was considered statistically significant.

\section{RESULTS}

A total of 440 patients completed the questionnaire. Sociodemographic characteristics of the participating patients are shown in Table 1. Distribution of the participating patients according to diagnosis are shown in Table 2. Of the patients with rheumatic diseases who participated in this study, 217 (49.3\%) were found to use the CAM method. There was no statistically significant difference between rheumatic diseases groups regarding the CAM use $(p>0.05)$. However, patients with RA were found to tend to CAM methods more. The CAM use of patients with rheumatic diseases participating in this study is shown in Figure 1. 
Table 1: Presents socio-demographic characteristics of the patient with chronic rheumatic diseases

\begin{tabular}{|c|c|c|}
\hline & & Mean(SD) \\
\hline & Age & $47.40 \pm 14.09$ \\
\hline & & n (\%) \\
\hline \multirow{2}{*}{ Gender } & Male & $144(32.7)$ \\
\hline & Female & $296(67.3)$ \\
\hline \multirow{4}{*}{ Marital status } & Married & $356(80.9)$ \\
\hline & Single & $57(13)$ \\
\hline & Divorced & $5(1.1)$ \\
\hline & Widow & $22(5)$ \\
\hline \multirow{4}{*}{ Education } & Illiterate & $42(9.5)$ \\
\hline & Primary school & $214(48.6)$ \\
\hline & Secondary school & $95(21.6)$ \\
\hline & University & $89(20.2)$ \\
\hline \multirow{6}{*}{ Occupation } & Officer & 61 (13.9) \\
\hline & Worker & $36(8.2)$ \\
\hline & Student & $22(5)$ \\
\hline & Housewife & $222(50.5)$ \\
\hline & Retired & $52(11.8)$ \\
\hline & Other & $47(10.7)$ \\
\hline \multirow{3}{*}{ Income } & $<500$ USD & $191(43.4)$ \\
\hline & 500-1500 USD & $207(47)$ \\
\hline & $>1500$ USD & $42(9.5)$ \\
\hline \multirow{2}{*}{ Place of residency } & Urban & $405(92)$ \\
\hline & Rural & $35(8)$ \\
\hline
\end{tabular}

USD: United States dollars

Table 2: Disease groups

\begin{tabular}{cc}
\hline & $\mathbf{n ~ ( \% )}$ \\
\hline OA & $179(40.6)$ \\
\hline FMS & $95(21.6)$ \\
\hline RA & $85(19.3)$ \\
\hline SpA & $35(8)$ \\
\hline CTD & $28(6.4)$ \\
\hline BD & $10(2.3)$ \\
\hline FMF & $8(1.8)$ \\
\hline
\end{tabular}

BD; Behçet's disease, CTD; connective tissue disease, FMF; familial mediterranean fever, FMS; fibromyalgia OA; osteoarthritis, , RA; rheumatoid arthritis, SpA; spondyloarthropathy,

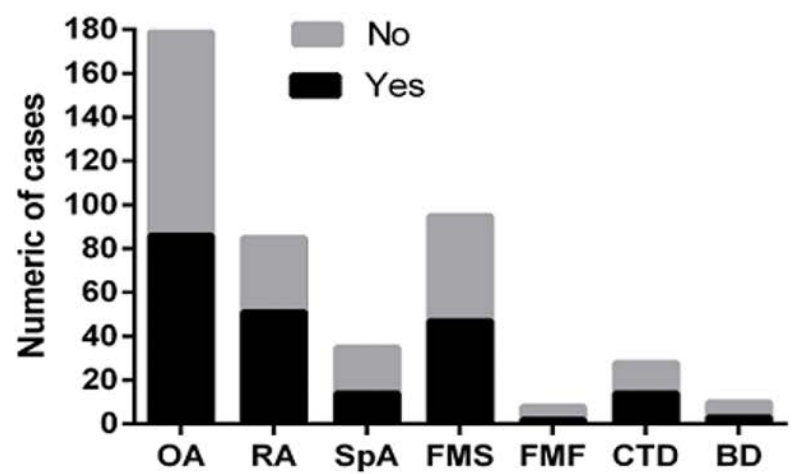

OA: Osteoarthritis, RA: Rheumatoid Arthri:is, SpA: Spondyloarthropathy, FMS: Fibromyalgia Syndrome, FMF: Familial

Mediterranean fever , CTD: Connective Tissue Discrder, BD: Behçet's Disease

Figure 1: Relationship between diagnosis and CAM use in patients included 
Table 3: CAM use

\begin{tabular}{|c|c|c|}
\hline & & n (\%) \\
\hline \multirow{8}{*}{ Method } & Herbal remedies & $126(58.1)$ \\
\hline & Tomb visit & $6(2.8)$ \\
\hline & Coiling up with fish & $2(0.9)$ \\
\hline & Leech & $10(4.6)$ \\
\hline & Knotting & $2(0.9)$ \\
\hline & Coiling up with wool & $10(4.6)$ \\
\hline & Products advertised & $38(17.5)$ \\
\hline & Other & $23(10.6)$ \\
\hline \multirow{7}{*}{ Reason for CAM use } & Belief for recovery & $164(75.6)$ \\
\hline & Due to difficulties in access to healthcare services & $1(0.5)$ \\
\hline & As no benefit from medical therapy & $11(5.1)$ \\
\hline & To avoid drug adverse effects & $25(11.5)$ \\
\hline & Manipulation by other people & $11(5.1)$ \\
\hline & Curiosity & $4(1.8)$ \\
\hline & Other reasons & $1(0.5)$ \\
\hline \multirow{4}{*}{ Reference } & Family and social network & $114(52.5)$ \\
\hline & Other patient & 28 (12.9) \\
\hline & Clinician & $6(2.8)$ \\
\hline & Media & 69 (31.8) \\
\hline
\end{tabular}

CAM: Complementary and alternative medicine

Table 4: CAM use relationship between education status and income

\begin{tabular}{|c|c|c|}
\hline & CAM (+) & CAM (-) \\
\hline & n (\%) & n (\%) \\
\hline \multicolumn{3}{|l|}{ Education } \\
\hline Illiterate & $17(40.5)$ & $25(59.5)$ \\
\hline Primary school & $92(43)$ & $122(57)$ \\
\hline Secondary school & $49(51.6)$ & $46(48.4)$ \\
\hline University & $59(66.3)$ & $30(33.7)$ \\
\hline \multicolumn{3}{|l|}{$P=0.001$} \\
\hline \multicolumn{3}{|l|}{ Income } \\
\hline$<500$ USD & $78(40.8)$ & $113(59.2)$ \\
\hline $500-1500$ USD & $113(54.5)$ & $94(45.5)$ \\
\hline$>1500$ USD & $26(61.9)$ & $16(38.1)$ \\
\hline$P=0.028$ & & \\
\hline
\end{tabular}

CAM: Complementary and alternative medicine, USD: United States dollars

Table 5: CAM use relationship between disease duration

\begin{tabular}{ccc}
\hline & CAM (+) & CAM (-) \\
\hline & $\mathbf{n ~ ( \% )}$ \\
\hline Disease duration & & \\
\hline Less than 1 year & $18(31)$ & $40(69)$ \\
\hline $1-10$ years & $168(70.9)$ & $26(29.1)$ \\
\hline $10-20$ years & $3(70.3)$ & $3(29.7)$ \\
\hline $20-30$ years & $2(100)$ & $0(0)$ \\
\hline Over 30 years
\end{tabular}

CAM: Complementary and alternative medicine, $\mathrm{P}=0.001$

The CAM methods used, the reason for using it, and who suggested it are shown in Table 3.

CAM was preferred by patients with a higher level of education and income. This was found to be statistically significant $(p<0.05)$. The use of CAM by the level of education and income is shown in Table 4 . As the duration of disease was prolonged, the rate of CAM use was also found to increase. This relationship was found to be statistically significant $(p<0.05)$. The duration of disease and the use of CAM are shown in Table 5.

The mean cost of CAM use was 48 (range: 1 to 1.300) United States dollars (USD) $\chi 2=60.167$. 


\section{DISCUSSION}

In this study, the use of CAM was found to be common in individuals with the chronic rheumatic disease. The use of CAM in individuals with the rheumatic disease was found to be related to the level of education and income. It was further observed that university graduates and those with high-income levels were more likely to use CAM. These findings in our study are consistent with the literature (17-20). In addition, unlike the literature, we found out that the use of herbal remedies among the CAM methods was more common in Turkish patients with rheumatic disease (18), which is one of our contributions to the literature. However, among individuals with the rheumatic disease, patients with RA were found to be more likely to prefer CAM in our study. It was further observed that physicians were less likely to encourage the use of CAM in individuals with rheumatic disease, unlike other studies in the literature. These findings in our study are new findings which are different from the literature $(18,21)$.

Despite the improvements in conventional treatment methods for chronic diseases, current evidence suggests increasing use of alternative treatment methods. A very insufficient published data exists as to CAM is used for what type of diseases and in which social classes (21). In the present study, the use of CAM was more common in patients with university education and in the patients with a higher level of income. The use of CAM brings about increasing healthcare costs. One study in the US reported an average cost of 27.6 USD for the use of CAM, whereas the average cost to the patient in the present study was 48 USD $(22,23)$.

Rheumatic diseases have a relapsing-remitting disease pattern and there is no cure for these groups of disorders. The studies have shown that patients make a trial of CAM methods before or after the diagnosis of pain relief or to treat the disease (24). The present study found that patients with a longer disease duration more commonly resorted to CAM methods. The use of CAM in rheumatic diseases is steadily increasing in recent years (25-28). It was demonstrated that patients with rheumatic disease commence the use of CAM methods for various reasons. Patients in the developed countries use CAM as per the physician's advice, whereas patient's relatives and media are the main elements promoting the use of CAM methods (29). In the present study, only $2.8 \%$ of the patients used CAM as per the physician's advice, whereas family and social circle had a share of $52.5 \%$. Although chiropraxis, acupuncture, massage, herbal remedies, and homeopathy are the most common CAM methods used by the patients with rheumatic disease in many countries, dietary modification and body-based practices, such as massage, manipulation and traction are the most commonly employed CAM method in Turkey (18). Unlike other studies, the use of herbal CAM methods was more common in patients with rheumatic disease in our study. We should note that Turkish patients with rheumatic diseases used CAM methods, including their cultural and religious beliefs.

The preference for CAM use varies depending on geographic location, ethnicity, educational level, socioeconomic factors, religious beliefs, and culture (30-32).

Patients with non-inflammatory rheumatic disease comprised the majority of patients with rheumatic disease using CAM in studies evaluating the use of CAM methods, whereas in Turkey, patients with RA were found to be more prone to the use of CAM $(18,21)$. In a survey by Cronan et al. (25), 84\% of the patients with OS or RA reported CAM use in the last six months. In the studies by Chandrashekara (26) and Zaman et al. (27), approximately $43 \%$ of patients with RA used CAM, whereas $46.9 \%$ of patients with RA in the study by Tokem et al. (28) used CAM. In the study by Ulusoy et al. (18), approximately half of the patients with rheumatic disease (46.2\%) experienced at least one method of CAM. Similar to other studies, patients with rheumatic disease in the present study (49.3\%) have used CAM since the diagnosis. The use of CAM was found to be the most common in patients with fibromyalgia syndrome among other rheumatic diseases. Lind et al. (21) reported CAM use in $91 \%$ of patients with fibromyal gia and $63 \%$ of patients with other rheumatic diseases.

There is an increasing rate of CAM use in rheumatic diseases despite the improvement in conventional treatment programs. One of the important drawbacks in this regard is the lack of knowledge about the effects and side effects of CAM method among physicians and the patients. The physicians are required to gain sufficient knowledge of evidencebased CAM methods with the advanced in modern medicine and technology. The limitations of the present study include small number of patients and conduction of this study in a local area.

In conclusion, the use of CAM is common in patients suffering from a chronic rheumatic disease and the use of herbal CAM methods is even more common in Turkey. Among patients with rheumatic disease, patients with RA more commonly resort to the methods of CAM. The use of CAM is more common in patients with university education and in patients with higher level of income. Physician's advice encouraging the use of CAM is less often in patients with rheumatic disease compared to the other studies. Further clinical studies are required to evaluate the rate of CAM use in patients with chronic rheumatic disease. 


\section{REFERENCES}

1. Nahin RL, Barnes PM, Stussman BJ, Bloom B. Costs of Complementary and Alternative Medicine (CAM) and Frequency of Visits to CAM Practitioners: United States, 2007. Natl Health Stat Report 2009;30(18):1-14.

2. Ramos-Remus C. Complementary and alternative practices in rheumatology, Best Practice \& Research Clinical Rheumatology 2008;22(4):741-57. https://doi.org/10.1016/j.berh.2008.05.001 PMid:18783748

3. Farzaei $\mathbf{M H}$, Farzaei $F$, Abdollahi $M$, Abbasabadi $Z$, Abdolghaffari $A H$, Mehraban $B$. A mechanistic review on medicinal plants used for rheumatoid arthritis in traditional Persian medicine. J Pharm Pharmacol 2016;68(10):1233-348. https://doi.org/10.1111/jphp.12606 PMid:27417522

4. Mbizo J, Okafor A, Sutton MA, Burkhart EN, Stone LM. Complementary and Alternative Medicine Use by Normal Weight, Overweight, and Obese Patients with Arthritis or Other Musculoskeletal Diseases. J Altern Complement Med 2016;22(3):227-36. https://doi.org/10.1089/acm.2014.0390 PMid:26938367

5. Comella NFL, Matilla MF, Castellano Cuesta JA. Have complementary therapies demonstrated effectiveness in rheumatoid arthritis? Reumatol Clin 2016;12(3):151-57. https://doi.org/10.1016/j.reuma.2015.10.011 PMid:26711840

6. Liu J, Pan J, Wang Y, Lin D, Shen D, Yang H. et al. Component analysis of Chinese medicine and advances in fuming-washing therapy for knee osteoarthritis via unsupervised data mining methods. J Tradit Chin Med 2013;33(5):686-91. https://doi.org/10.1016/S0254-6272(14)60043-1

7. Rajbhandary R, Bhangle S, Patel S, Sen D, Perlman A, Panush RS. Perspectives about complementary and alternative medicine in rheumatology. Rheum Dis Clin North Am 2011;37(1):1-8. https://doi.org/10.1016/j.rdc.2010.11.008 PMid:21220081

8. Marsh J, Hager C, Havey T, Sprague S, Bhandari M, Bryant D. Use of alternative medicines by patients with OA that adversely interact with commonly prescribed medications. Clin Orthop Relat Res 2009;467(10):2705-722. https://doi.org/10.1007/s11999-009-0764-3 PMid:19255814 PMCid:PMC2745447

9. Dias $P A$, Guimarães $A B$, Albuquerque Ade $O$, de Oliveira KL, Cavalcante $M L$, Guimarães SB. Short-term complementary and alternative medicine on quality of life in women with fibromyalgia. J Integr Med 2016;14(1):29-5. https://doi.org/10.1016/S2095-4964(16)60235-2

10. Chatfield SM, Dharmage SC, Boers A, Martin BJ, Buchanan RR, Maksymowych WP, et al. Complementary and alternative medicines in ankylosing spondylitis: a cross-sectional study. Clin Rheumatol 2009;28(2):213-17. https://doi.org/10.1007/s10067-008-1029-3 PMid:18985421

11. Breuer GS, Orbach $H$, Elkayam $O$, Berkun $Y$, Paran $D$, Mates $M$, et al. Use of complementary and alternative medicine among patients attending rheumatology clinics in Israel. Isr Med Assoc J 2006;8(3):184-87. PMid:16599054

12. Klingberg E, Wallerstedt SM, Torstenson T, Håwi G, Forsblad-d'Elia H. The use of complementary and alternative medicine in outpatients with inflammatory rheumatic diseases in Sweden. Scand J Rheumatol 2009;38:472-80. https://doi.org/10.3109/03009740902994280 PMid:19922024

13. Lee MS, Yang $\mathrm{CY}$, Lee $\mathrm{SI}$, Joo MC, Shin $\mathrm{BC}$, Yoo WH, et al. Use of complementary and alternative medicine by rheumatoid arthritis patients in Korea. Clin Rheumatol 2008;27(1):29-33. https://doi.org/10.1007/s10067-0070646-6 PMid:17541497

14. Buchbinder R, Gingold M, Hall S, Cohen M. Nonprescription complementary treatments used by rheumatoid arthritis patients attending a communitybased rheumatology practice. Intern Med J 2002;32:208-14. https://doi.org/10.1046/j.1445-5994.2002.00213.x PMid:12036218

15. Gabriel SE, Michaud K. Epidemiological studies in incidence, prevalence, mortality, and comorbidity of the rheumatic diseases. Arthritis Res Ther. 2009;11(3):229. https://doi.org/10.1186/ar2669 PMid:19519924 PMCid:PMC2714099

16. Re ML, Schmidt S, Güthlin C. Translation and adaptation of an international questionnaire to measure usage of complementary and alternative medicine (I-CAM-G). BMC Complement Altern Med. 2012 20;12:259. https://doi.org/10.1186/1472-6882-12-259

17. Verkamp EK, Flowers SR, Lynch-Jordan AM, Taylor J, Ting TV, Kashikar-Zuck S. A survey of conventional and complementary therapies used by youth with juvenile-onset fibromyalgia. Pain Manag Nurs 2013;14(4):244-50. https://doi.org/10.1016/j.pmn.2012.02.002 PMid:24315277 PMCid:PMC3857559 
18. Ulusoy H, Güçer TK,Aksu. M, Arslan \$̧, Habiboğlu A, Akgöl G, et al. The Use of Complementary and Alternative Medicine in Turkish Patients with Rheumatic Diseases. Turk J Rheumatol 2012;27(1):31-7. https://doi.org/10.5606/tjr.2012.004

19. Kav S, Hanoğlu Z, Algıer L. Use of Complementary and Alternative Medicine by Cancer Patients in Turkey: A Literature Review. International Journal of Hematology and Oncology 2008;18(1):32-6.

20. Millar WJ. Use of alternative health care practitioners by Canadians. Revue Canadienne de Sante Publique 1997;88(3):154-58. PMid:9260354

21. Lind BK, Lafferty WE, Tyree PT, Diehr PK, Grembowski DE. Use of complementary and alternative medicine providers by fibromyalgia patients under insurance coverage. Arthritis and Rheumatism 2007;57(1):71-6. https://doi.org/10.1002/art.22471 PMid:17266066 PMCid:PMC1853385

22. Eisenberg DM, Kessler RC, Foster C, Norlock FE, Calkins DR, Delbanco TL. Unconventional medicine in the United States. Prevalence, costs, and patterns of use. The New England journal of medicine 1993;328(4):246-52. https://doi.org/10.1056/NEJM199301283280406 PMid:8418405

23. MacLennan AH, Wilson DH, Taylor AW. Prevalence and cost of alternative medicine in Australia. The Lancet 1996;347(9001):569-73. https://doi.org/10.1016/S0140-6736(96)91271-4

24. Ramos-Remus C, Watters CA, Dyke L, Suarez-Almazor ME, Russell AS. Assessment of health locus of control in the use of nonconventional remedies by patients with rheumatic diseases. The Journal of Rheumatology 1999;26(11):2468-74. PMid:10555911

25. Cronan TA, Kaplan RM, Kozin F. Factors affecting unprescribed remedy use among people with self-reported arthritis. Arthritis Care and Research 1993;6(3): 149-55. https://doi.org/10.1002/art.1790060307 PMid:8130291

26. Chandrashekara S, Anilkumar T, Jamuna S. Complementary and alternative drug therapy in arthritis. The Journal of the Association of Physicians of India 2002;50:225-27. PMid:12038653

27. Zaman T, Agrawal S, Handa R. Complementary and alternative medicine use in rheumatoid arthritis: an audit of patients visiting a tertiary care centre. National Medical Journal of India 2007;20(5):236-39. PMid:18254519

28. Tokem Y, Parlar Kilic S, Ozer S, Nakas D, Argon G. A multicenter analysis of the use of complementary and alternative medicine in Turkish patients with rheumatoid arthritis: holistic nursing practice review copy. Holist Nurs Pract 2014;8(2):98-05. https://doi.org/10.1097/HNP.0000000000000016 PMid:24503747

29. Wahner-Roedler DL, Vincent A, Elkin PL, Loehrer LL, Cha SS, Bauer BA. Physicians Attitudes Toward Complementary and Alternative Medicine and Their Knowledge of Specific Therapies: A Survey at an Academic Medical Center. Evid Based Complement Alternat Med 2006; 3(4):495-01. https://doi.org/10.1093/ecam/nel036 PMid:17173114 PMCid:PMC1697740

30. Ernst $E$, Cassileth BR. The prevalence of complementary/alternative medicine in cancer. A systematic review. Cancer 1998;83(4):777-82. https://doi.org/10.1002/(SICI)1097-0142(19980815)83:4<777::AIDCNCR22> 3.0.CO;2-O

31. Begbie SD, Kerestes ZL, Bell DR. Patterns of alternative medicine use by cancer patients. Med J Aust 1996;165(10):545-48. PMid:8941239

32. Risberg T, Lund E, Wist E. Use of non-proven therapies. Differences in attitudes between Norwegian patients with non-malignant disease and patients suffering from cancer. Acta Oncol 1995;34(7):893-01. https://doi.org/10.3109/02841869509127201 PMid:7492377 